This item was submitted to Loughborough's Research Repository by the author.

Items in Figshare are protected by copyright, with all rights reserved, unless otherwise indicated.

\title{
A bricolage perspective on technological innovation in emerging markets
}

\section{PLEASE CITE THE PUBLISHED VERSION}

http://dx.doi.org/10.1109/TEM.2015.2494501

PUBLISHER

(c) IEEE

\section{VERSION}

AM (Accepted Manuscript)

\section{PUBLISHER STATEMENT}

This work is made available according to the conditions of the Creative Commons Attribution-NonCommercialNoDerivatives 4.0 International (CC BY-NC-ND 4.0) licence. Full details of this licence are available at: https://creativecommons.org/licenses/by-nc-nd/4.0/

\section{LICENCE}

CC BY-NC-ND 4.0

\section{REPOSITORY RECORD}

Gurca, Andrei P., and M.N. Ravishankar. 2015. "A Bricolage Perspective on Technological Innovation in Emerging Markets”. Loughborough University. https://hdl.handle.net/2134/19438. 


\section{A bricolage perspective on technological innovation in emerging markets}

Abstract. Product innovation strategies of emerging market companies are increasingly challenging conventional wisdom. Drawing on a qualitative case study of Mahindra Reva, the only electric vehicle producer in India, the paper explores how a bricolage strategy enabled a resource-constrained emerging market firm to deliver affordable, innovative and high-tech products with minimal capital investments. The findings of the study illustrate how multiple forms of bricolage can be implemented and managed at organizational and inter-organizational levels. They show how different bricolage activities relate to different stages of the new product development process and further, highlight the complementarities between bricolage and engineering activities. The paper argues that bricolage, which is typically regarded as a behavioural trait or skill that allows entrepreneurs and innovators to operate in challenging environments, can also be a carefully planned and executed strategy conducive to innovation. Thus, it suggests that a cost-effective bricolage strategy can underpin emerging market companies' development of discontinuity-creating and market disrupting technology products.

Managerial Relevance Statement. This paper shows how emerging market managers can turn their firms' resource limitations into significant cost advantages through creative resource recombinations and innovative collaborations, potentially disrupting global markets with high-tech discontinuous innovations. In addition, the paper can help managers from developed countries derive "contextual intelligence" which is often crucial for the development and deployment of successful business models in emerging markets.

Keywords: technological innovation, qualitative case study, emerging markets, bricolage, disruptive innovations. 


\section{Introduction}

In emerging markets ${ }^{1}$, surprising and unexpected (at least from the perspective of extant management theory) practices often underpin the development of innovative products $[\mathrm{I}],[2]$. Research hints at two possible reasons. Firstly, companies from emerging markets may not always possess the resources or capabilities required for the pursuit of technology innovations (see [3], [4]). Given the institutional voids and inefficient capital markets, companies are often unable to raise adequate financing for their innovative projects [5], [6]. Second, even if emerging market companies had such resources, they might find it counterproductive to engage in high-budget $R \& D$ processes as the resulting products may turn out to be too expensive for their customers. In recent years, several emerging market companies have entered the fray with potentially disruptive product innovations such as Tata Nano - the ultraaffordable car [7] and ChotuKool - the portable refrigerator [8]. Such emerging market companies are paring down mature technologies to develop simpler and more affordable innovative products that serve the same practical purposes as those developed by MNEs from developed countries. Other companies such as Chinese computer makers Dawning [9] and Lenovo [I0] are incorporating top technologies in low(er)-cost products. All these firms intend to tap into the growing consumption in developing countries, which is predicted to create a market of US\$ 30 trillion by 2025 [II].

Firms in emerging markets typically face three types of constraints: lack of material resources, lack of affluent customers, and lack of time [I2]. Scholarly research is only beginning to explore and explain how despite a slew of such debilitating constraints, emerging market firms are able to develop innovative products at relatively low-costs. To date, very few studies have opened the 'black box' of emerging market innovations and explored in detail the organizational and inter-organizational processes underpinning the development of frugal and low-cost innovations. Thus, our main research question can be articulated as follows: How do emerging market firms manage to overcome serious

\footnotetext{
${ }^{1}$ By 'emerging markets' we broadly refer to rapidly growing countries, which are struggling with inefficient and less than robust institutional infrastructures. Emerging markets include countries like Brazil, Russia, China, India, South Africa, Turkey, Indonesia and Mexico.
} 
contextual constraints and develop innovative, cost-effective and potentially disruptive products? In order to address this question, we draw on the literature on bricolage [I3], [I4]. The notion of bricolage has its roots in anthropology and is particularly relevant to emerging markets because it draws attention to firms' capabilities to make do with the resources at hand and recombine them to handle novel problems in difficult contexts. In particular, it provides rich insights into the processes underpinning the achievement of what has been termed by practitioners and scholars as jugaad solutions [I5] and frugal engineering outcomes [I6] in emerging markets.

This paper builds on a qualitative case study of Mahindra Reva, India's sole electric vehicle (EV) manufacturer and explains the complexity and sophistication of the innovation process in emerging markets under an overarching bricolage framework. The study illustrates multi-level bricolage-based processes and demonstrates how a creative recombination of resources in tandem with component bricolage and collaborative bricolage helps manage the technology innovation process in resource-constrained emerging markets. The paper makes four main contributions. First, it shows how cost-effective bricolage processes can be central to the development of potentially technological discontinuity-creating and market-disrupting products. Second, the paper shows how in addition to being a skill and an antecedent of innovation and entrepreneurship (see [I], [I3]), bricolage, under certain conditions, can also be a deliberately orchestrated strategy. Third, the paper demonstrates how various types of bricolage activities relate to different stages of the new product development process in emerging markets. Finally, the paper provides insights into the complementarities between bricolage and engineering activities.

\section{Bricolage}

Bricolage finds mention in a diverse range of settings. It has been used to explore and explain entrepreneurship and resource creation [I3], [17], [18], development and utilization of information technology artefacts [19] and organizational resilience and improvisation [20]. The notion of bricolage is unusual and somewhat counter-intuitive in that it demonstrates how deviation from established practices can help foster cutting-edge technological innovation. Further, it illuminates how highly- 
pragmatic strategies are enacted in practice (see [7]; [8]). Bricolage goes back to the work of French anthropologist Claude Levi-Strauss [I4] who invoked an imagery of two opposing figures - the engineer and the bricoleur. The engineer attempts to design an optimal solution for problems, while the bricoleur solves problems by relying exclusively on "whatever is at hand" [I4, p. I7]. This 'making do" with resources at hand reflects a fundamental attitudinal and behavioural trait - an inclination towards action and active tackling of challenges rather than extensive contemplation and evaluation of the situation at hand [13], [I4]. Thus, bricolage-work is no longer viewed as a "shameful" activity that pales in comparison with heroic and expensive $R \& D$ processes $[2 \mathrm{I}]$. Rather it is now increasingly seen as a legitimate approach to technology innovation and product development [I8].

Baker and Nelson [13] expanded upon Levi-Strauss' ideas and emphasized two important features of bricolage. First, the person or organization engaging in bricolage creatively combines the resources at hand and uses them in new contexts or applications, departing substantively from their original or conventional usage. Bricolage involves assigning meaning and purpose to resources which others find useless or inadequate [I3]. Therefore, bricolage is not only the creation of new from old but also the creation of "something from nothing" or of "more from less" [13, p. 357]. From this broader perspective, bricolage is the creative and strategic deployment of diverse, generic, nonspecialized resources in novel contexts.

The second crucial feature of bricolage relates to the bricoleur's refusal to be cognitively constrained by current practices and methodologies [13]. Weick [22] argued that restrictions and constraints on behaviour originate from the a priori acceptance of prevailing assumptions and prescriptions which results in a "failure to act" (p. I49), thus preventing actors from testing whether something can actually be achieved. An important characteristic of the bricoleur is the conscious disregard for extant practices and methodologies and the concomitant engagement in a process of experimentation, which continuously tests the limits of the environment [I7]. Baker and Nelson [I3] also found that the perpetuated reliance on bricolage allows firms to survive but stifles organizational growth. The reason is that, although bricolage can sometimes render "brilliant unforeseen results" [I4, 
p. 17], its outcomes are usually hybrid, imperfect artefacts which serve the intended purposes but require significant improvement [19]. Tata Nano's reported failure to meet international safety standards is a case in point [23]. Notwithstanding such shortcomings, there is evidence to suggest that the selective use of bricolage at key stages in the life of the organizations followed by a return to prevalent practices and methodologies can lead to consistent firm growth [I3].

Bricolage activities are based on a 'repertoire' of resources [I4], [24]. The repertoire "consists of material and immaterial resources that are collected independently of any particular project or utilization" [24, p. I37]. In the original depiction of bricolage, the bricoleur's repertoire was finite and closed [I4]. However, in more recent studies of bricolage, the repertoire is seen as a dynamic construct - the bricoleur continues to acquire and use resources, cutting costs and learning new things along the way (see [13]; [24]). Despite its potentially large volume, the bricoleur has an intimate knowledge of the repertoire based on an exhaustive inventorying of all resources [I4], [24]. The bricolage literature encompasses individual activities (e.g., [24]) as well as organizational (e.g., [25]) and interorganizational processes (e.g., [I8]). When performed at organizational or inter-organizational levels, bricolage becomes a collective process [24]. Collective bricolage "is more than the ex-post connection" of arrangements or solutions developed by individual bricoleurs [24, p. I43]. It is a lengthy and complex process which involves the disclosure of separate repertoires to the point where the bricoleurs become familiar with the shared repertoire "as if it was personally constituted by each of them" [24, p. I43]. For instance, Garud and Karnoe [18] used collective bricolage as an analogy for the distributed agency involved in the development of wind turbine technology in Denmark. They showed how a network of stakeholders comprising producers, users, regulators, and evaluators generated inputs which eventually contributed to the creation of a profitable technological path for the entire wind turbine industry. The network-based, incremental approach to technology development allowed resourceconstrained Danish innovators to successfully outwit munificent US competitors who adopted a more expensive 'technological breakthrough' seeking strategy.

\section{Technological innovation in emerging markets and bricolage}




\section{A bricolage perspective on technological innovation in emerging markets}

In general, emerging market companies are perceived as "technological followers" that are catching up with competitors from developed countries in terms of manufacturing capabilities [26]. These emerging market companies typically pare down mature technologies to meet the cost requirements of emerging market customers. Two recent empirical studies of emerging market innovations provide good illustrations of this argument: Tata Motors' development of Nano, the world's cheapest car [7] and Godrej \& Boyce's development of a small portable cooling unit to meet the needs of customers in rural India [8]. Tata Motors used an adapted motorcycle starter motor and a two-cylinder engine, also specific to motorcycles, to cut the cost of its Nano car [7]. Similarly, Godrej \& Boyce replaced the compressor, cooling tubes and refrigerant of a conventional refrigerator with a fan resembling those which prevent computers from overheating and a chip that cools when electricity is applied [8]. These examples suggest that low-cost innovations achieved through the paring down of mature technologies often involve bricolage activities such as the creative recombination of non-specialized parts and components.

Increasingly, bricolage processes (e.g. different forms of collective bricolage) also appear to be used by emerging market companies to develop cutting edge technological products. The case of relatively nascent industries such as regenerative medicine (see [27]) and electric vehicles (which is the focus of this paper) offer good illustrations. In a recent study, McMahon and Thorsteinsdottir [27] showed how emerging market innovators in the regenerative medicine industry developed systemic innovation capabilities and products through contributions from multiple entities such as firms, governmental bodies, universities and research centres, hospitals, cord blood banks, and in vitro fertilization clinics. It seems that at least some emerging market companies are poised to become "technological leaders" through innovative collaborations and recombination of resources, which chime with prior studies on bricolage (see [I8]). This reliance on networking and relationship-based strategies is obviously closely linked to institutional voids such as the lack of intermediary and support services, poorly enforced regulations, and poor infrastructure [5]. Although this body of literature does not explicitly use the term, it hints at a conscious managerial deployment of bricolage-based approaches in 
the new technology development process. In the next sections of the paper, we develop these arguments further through an in-depth qualitative case study of an Indian electric vehicle (EV) manufacturing company.

\section{Case Background}

The Maini Group established the Reva Electric Car Company (RECC) in July 2000 and launched its first car - Reva - in 200I. The Reva was a small two-door EV powered by a $48 \mathrm{~V}$ lead-acid battery pack. It had a driving range of $80 \mathrm{~km}$, a top-speed of $65 \mathrm{~km} / \mathrm{hr}$ and carried a price-tag of US\$5,000. In 2003, the Reva became the first EV to qualify for the European Union roadworthiness standard. In 2004, the Reva was launched in the UK under the brand name G-Wiz (or Green Wizard). The car proved popular in London where EV drivers were offered numerous benefits such as congestion tax exemption, free charging, and free parking. The first Reva models with lithium-ion batteries were launched in 2007. By the time its production was ceased on 2012, over 4600 Reva cars had been sold in more than 25 countries.

In 2010, the Indian multinational automaker Mahindra and Mahindra Ltd. (M\&M) bought a controlling 55.2\% stake in RECC. M\&M currently produces a wide range of MUVs (multi-utility vehicles), SUVs, pick-up trucks, commercial vehicles, tractors and two-wheelers. The newly formed Mahindra Reva Electric Vehicle Company has largely remained an independent entity and continues to be led by Reva’s founding family. In 2013, Mahindra Reva launched a new model, the Mahindra e2o.

Slightly bigger than its predecessor, the e2o was powered by a $48 \mathrm{~V}$ lithium-ion battery pack, had a driving range of $100 \mathrm{~km}$ and a top-speed of $8 \mathrm{I} \mathrm{km} / \mathrm{hr}$. The car was priced at approximately US\$ I2,000 and offered a wide range of telematics applications. At the time of this study, the Mahindra e2o remained the most affordable EV in the world.

\section{Research Methods}

We adopted the qualitative case study method [28] to generate in-depth accounts and to develop rich insights into the organizational processes supporting technological innovation at Mahindra Reva. We chose to study Mahindra Reva given the novelty and atypical nature of the setting - it is one of the few 
emerging market companies producing electric vehicles. Further, despite being a small (i.e. less than 400 employees) indigenous company, it has managed to produce competitive electric cars for over a decade. We (the two authors) collected empirical material (face-to-face interviews and field observations) for this study between June and September 2013 at Mahindra Reva's ${ }^{2}$ headquarters and production facilities in Bangalore, India. We conducted semi-structured interviews in English with 48 informants (see Table I below). On average, each interview lasted for about 50 minutes. In total, we collected close to 40 hours of interview data. With two exceptions, all interviews were recorded with the consent of the informants. By conducting interviews with informants at various hierarchical levels, we were able to obtain a variety of views and triangulate the empirical material. We asked a number of open-ended questions about the company's history, challenges faced, strategies implemented and the management of relationships with suppliers and partner organizations. The interviews were semistructured and informants were given the opportunity to raise issues, which they felt were central to the company's innovative technology development process. We also tried to embed ourselves in the setting and personally experience life in the organization. We were given office space on the company's premises, which allowed us to observe employees in action. Observing everyday activities helped us better understand our informants' world-views and the jargon/EV-specific language they used during the interviews. During our fieldwork in June-September 2013, we were at the company's production facilities between $9 \mathrm{am}-5 \mathrm{pm}$ on all working days. We used this opportunity to interact with and observe employees in a number of informal settings, (e.g., the company cafeteria). We travelled every day in the company's shuttle bus to and from the company's production facilities on the city's outskirts. This also gave us numerous opportunities to interact informally with a number of employees.

Table I. Interviews

\begin{tabular}{|l|c|}
\hline \multicolumn{1}{|c|}{ Informant category } & $\begin{array}{c}\text { Number of } \\
\text { interviews }\end{array}$ \\
\hline Senior managers & $\mathrm{I} 2$ \\
\hline
\end{tabular}

\footnotetext{
${ }^{2}$ We use the term Mahindra Reva consistently throughout the paper. However, the accounts and events presented in this section often chronologically precede the 2010 take-over by Mahindra and Mahindra.
} 


\begin{tabular}{|l|c|}
\hline Middle managers & I4 \\
\hline Front-line employees & 22 \\
\hline
\end{tabular}

In order to complement the primary data, we also collected two categories of archival data. First, we collected documents and printed materials produced by Mahindra Reva including organization charts, internal publicity and newsletters, marketing hand-outs and company magazines. This material allowed us to accurately position in time the accounts and events described by our informants. Second, we collected a number of articles and reviews about Mahindra Reva and its products, which had appeared in newspapers, business and trade magazines and online blogs. They helped us triangulate our informants' perspective of the innovation process and its outcomes with the views of other independent observers. On the whole, the interviews and documents analysed for this study trace events and outcomes spanning about two decades.

\section{Data analysis}

Once senior managers at Mahindra Reva formally agreed to take part in our study, we began a preliminary process of analysing the publicly available published material (e.g., articles in the business press) about the company. At the same time, we turned to the scholarly literature to identify a relevant theoretical scaffolding, which could inform our investigation and serve as a sensitizing analytical device. As Blumer [29, p.7] has observed, a sensitizing concept "gives the user a general sense of reference and guidance in approaching empirical instances". EVs had long been viewed as a disruptive technology (see [30]). In addition, there were several references on the Mahindra Reva website to the frugality of the company's product development process. Thus, while there was no apriori hypothesis, we started the fieldwork with the literature on 'frugal engineering' and 'disruptive innovation' serving as broad sensitizing devices.

At the end of our fieldwork, we had collected vast amounts of both primary and secondary data. We adopted a 'selective' scheme [3I] to identify central themes in our dataset. We identified several 'first order' themes, which we labelled as constraints, frugality, challenging status quo, improvisation, partnership, collaboration, adaptability and resilience. At this stage we realized that the notion of frugal engineering could not fully explain our data. Through an iterative process of 
comparison between the emergent findings and extant theory, we arrived at Baker and Nelson's [I3] work on bricolage, which provided a good characterization of the technological innovation process described by our informants. The notion of bricolage allowed us to move the analysis to a higher level of abstraction. We revisited and compared the data extracts corresponding to the previously developed first order themes with the core concepts of the bricolage literature. We were thus able to develop three larger second-order themes, which related closely to the various forms of bricolage employed by Mahindra Reva. Two of these themes - resource recombinations and collaborative bricolage corresponded closely with Baker and Nelson's [13] arguments about recombination of resources for new purposes and Garud and Karnoe's [I8] ideas about collective bricolage respectively. The third theme - component bricolage - was not aligned with any extant categorizations in the scholarly literature. Lastly, we verified if there were any significant data strands which did not fit into our second-order themes. We discovered that although bricolage accurately explained Mahindra Reva's strategy at a macro level, in reality the strategy was implemented through a mixture of bricolage and hard-core engineering practices. Consequently, we developed a fourth theme, which explained how bricolage related to engineering methods in the technological innovation process.

\section{Findings}

We found that three bricolage processes crucially underpinned Mahindra Reva's technological innovation and product development strategies: recombination of resources for new purposes, component bricolage, and collaborative bricolage. We also discovered that Mahindra Reva creatively integrated bricolage and engineering methodologies. We explain these findings in greater detail below.

Recombination of resources for new purposes

This category of bricolage activities and processes refers to instances where available and easily accessible resources (e.g. some types of tools and raw materials) are deployed in new contexts or applications departing from their conventional usage [13]. A detailed listing of the creative use of resources at Mahindra Reva can be found in Table 2 below. According to our informants, two factors enabled them to recombine resources for new purposes. First, being a new entrant in the automotive 
industry and having no prior involvement in the production of conventional, internal combustion (IC) cars allowed the company to challenge shared assumptions in the industry about what could and could not be done. Second, as a small start-up company they did not have the money to invest on established practices and resources.

"When you are new in business you can ask why this has to be done this way, why can't it be done differently. Because EVs were different from what others were doing, we were able to think differently. We had the freedom and confidence to challenge conventional ways. If you do something that many others do, you tend to be more cautious about departing from the established line. [...] Also, we could only afford low capital investments in production equipment." (CEO)

The founders felt their expertise with battery-operated handling equipment would provide a reasonable starting point for the EV venture. The Maini Group had developed useful knowledge about low-speed in-plant equipment which could be tweaked and potentially redeployed in the new context of on-road vehicles. Initially, the company used lead-acid batteries to power their EVs. The lead-acid batteries had been developed originally for the ignition of conventional IC engines. The original composition and size of such batteries was inadequate for EVs. Mahindra Reva's engineers adjusted the chemical composition of the batteries and put together big battery packs comprising over 20 individual batteries. Later, the company moved to lithium-ion batteries. These batteries had been developed originally for small portable electronic devices. In order for such non-specialized resources to meet the requirements of their newly assigned functionality, the company collaborated closely with their suppliers and experimented extensively (see Table 2 below).

Table 2. Creative use of resources

\begin{tabular}{|l|l|l|l|}
\hline \multicolumn{1}{|c|}{ Resources } & $\begin{array}{c}\text { Conventio- } \\
\text { nal } \\
\text { application }\end{array}$ & $\begin{array}{l}\text { Innovative } \\
\text { application }\end{array}$ & \multicolumn{1}{|c|}{ Illustrative quotes } \\
\hline $\begin{array}{l}\text { Knowledge } \\
\text { and expertise } \\
\text { with low- } \\
\text { speed, }\end{array}$ & $\begin{array}{l}\text { Electric } \\
\text { forklifts and } \\
\text { indoor, } \\
\text { electric }\end{array}$ & $\begin{array}{l}\text { On-road } \\
\text { electric } \\
\text { vehicles }\end{array}$ & $\begin{array}{l}\text { "Electric forklifts gave us a preliminary understanding } \\
\text { of the requirements of working with batteries, } \\
\text { chargers, electric motors, controllers etc. We } \\
\text { understood fabrication, assembly lines, electronics, and } \\
\text { most importantly we understood small batch } \\
\text { production. In this EV business we deal with a number }\end{array}$ \\
\hline
\end{tabular}




\begin{tabular}{|c|c|c|c|}
\hline equipment & & & $\begin{array}{l}\text { of different models in small batches, unlike a typical } \\
\text { car or motorcycle company." (CEO - Maini Group) }\end{array}$ \\
\hline $\begin{array}{l}\text { Lead-acid } \\
\text { batteries }\end{array}$ & $\begin{array}{l}\text { Ignition for } \\
\text { IC vehicles }\end{array}$ & $\begin{array}{l}\text { Power for } \\
\text { EVs }\end{array}$ & $\begin{array}{l}\text { "If you take a lead-acid battery off the shelf and try to } \\
\text { drive a car on it you will kill it in a matter of seconds. } \\
\text { We 'worked" the chemistry and developed battery } \\
\text { packs on which cars could be driven for over three } \\
\text { years." (Senior Manager - Mobility Solutions) }\end{array}$ \\
\hline $\begin{array}{l}\text { Lithium-Ion } \\
\text { batteries }\end{array}$ & $\begin{array}{l}\text { Portable } \\
\text { electronic } \\
\text { devices }\end{array}$ & $\begin{array}{l}\text { Power for } \\
\text { EVs }\end{array}$ & $\begin{array}{l}\text { "We had to develop big battery packs for the Reva L- } \\
\text { ion cars weighing up to } 250 \mathrm{~kg} \text { by putting together } \\
\text { individual Li-Ion cells weighing about } 50 \text { grams each. } \\
\text { Since each battery cell needed monitoring, hundreds of } \\
\text { wires would come out of each one of them, checking } \\
\text { the power and the voltage. [...] We placed a } \\
\text { microchip in each battery cell to absorb all this } \\
\text { information and transmit it to the Intelligent Energy } \\
\text { Management System." (Founder and former CEO) }\end{array}$ \\
\hline $\begin{array}{l}\text { Plastics } \\
\text { produced } \\
\text { through } \\
\text { vacuum } \\
\text { forming and } \\
\text { rotation } \\
\text { moulding }\end{array}$ & $\begin{array}{l}\text { a) } \\
\text { Aeronautics; } \\
\text { b) Liquid } \\
\text { storage } \\
\text { facilities }\end{array}$ & $\begin{array}{l}\text { Exterior } \\
\text { body parts } \\
\text { for EVs }\end{array}$ & $\begin{array}{l}\text { "In India, there is a lot of traffic and lots of light } \\
\text { accidents. We needed something with high impact } \\
\text { strength. [...] We went for plastic made by vacuum } \\
\text { forming, which is used to make canopies for military } \\
\text { aircrafts and 'bubbles' for helicopters." (Senior } \\
\text { Manager - Prototypes) } \\
\text { "For the plastic in the bumpers of our first cars, we } \\
\text { used the 'rotation moulding' process, which is } \\
\text { generally used for water tanks. Nobody had used it for } \\
\text { automobiles before, but we found that if you use the } \\
\text { right equipment, processes and materials, it can be } \\
\text { used for cars quite successfully." (CEO) }\end{array}$ \\
\hline $\begin{array}{l}\text { Basic EV } \\
\text { components }\end{array}$ & $\begin{array}{l}\text { Typical EV } \\
\text { functions }\end{array}$ & $\begin{array}{l}\text { Testing } \\
\text { equipment }\end{array}$ & $\begin{array}{l}\text { "To test the battery, we used the motor controller and } \\
\text { developed a software to discharge the battery just as it } \\
\text { would be done in the car. When we went to the } \\
\text { battery testing facility in Kerala, they said that the } \\
\text { standard we were looking for would cost us around } \\
\text { Rs. I.5 crore (US\$ } 0.3 \text { million approximately) - we } \\
\text { developed our own battery testing facility for Rs. } 2 \\
\text { lakh (US\$ 4,OOO approximately)." (Founder and } \\
\text { former CEO) }\end{array}$ \\
\hline
\end{tabular}

The company could not afford to invest in metal sheet stamping equipment for the cars' exterior body. According to our informants, such an investment would have been impossible to amortise considering the low volumes the company was expecting to sell initially. Further, the use of metal body parts would have required a painting shop which was not only very expensive but also highly polluting, thereby conflicting with the 'environmentally conscious' values espoused by the company. Thus, they started exploring plastics as an alternative to metal sheets. In addition to requiring lower investments in manufacturing equipment, plastic body parts were recyclable, significantly lighter and dent-resistant. 
The development of an innovative product through unconventional processes and materials involves testing of numerous configurations of resources. As the cost of the typical testing equipment was beyond the company's resources, company engineers developed an in-house low-cost testing gear only using resources at hand such as basic EV parts and components.

"We innovated the testing rigs not from intent but from compulsion - resources were sparse and as long as the contraption did what it was supposed to do, it didn't matter what it looked like. [...] Overall, our in-house Testing Division frugally designed I2 testing rigs at around I\% of the cost of standard testing equipment, thereby saving some US\$ 20 million.” (Founder and former CEO) Component bricolage

Our definition of component bricolage is relatively straight-forward: the creation of original and innovative systems, relying mainly on off-the-shelf components, which were initially designed and developed for other vehicles.

"Individual parts such as the batteries, motor, wheels or tyres do not make a car on their own. The integrated system is where the added value comes from. Our value proposition is not going to be affected by using individual components which are less original or are already available. Some amount of standardized components, even those available off-the shelf, will give us a good cost-performance balance, while some amount of non-standardized original items will help add some interlocking between us and the customers." (Middle manager - Mobility Solutions)

With a lion's share of its resources dedicated to R\&D activities and another important chunk invested in the plant and assembly line, the company had little capital available for the development of components in non-critical areas such as mechanical parts, and interior and exterior design elements. In order to overcome these challenges, the company's engineers tried to use wherever possible (i) common or standard components which could be manufactured using the suppliers' existing capabilities without additional investments in tools and equipment or (ii) Mahindra Reva original parts in multiple projects to spread tooling costs and increase component volumes. Further, the company was faced with a very 
price-sensitive customer base. Any development and tooling costs associated with non-critical components could transfer to the selling price of the EV and negatively impact sales.

"We are trying to 'commonize' most of the parts to reduce the tooling investment and the time costs. The investment in tooling will get loaded on to the manufacturing cost of the component and eventually on to the selling price of the vehicle. We also try to use similar parts in two or more projects so that the development cost may get distributed and the cost burden on the consumer gets reduced." (Middle manager - New Product Development)

After Mahindra \& Mahindra became a majority shareholder in the Mahindra Reva venture, the component bricolage process was significantly simplified. Since the parent company was producing a wide range of automobiles, Mahindra Reva engineers and designers were given the opportunity to 'bricolate' with a number of previously IP restricted components originally used on Mahindra \& Mahindra models. Moreover, Mahindra \& Mahindra was involved in joint-ventures with other global auto-makers which led to the introduction of international models in the Indian market under the Mahindra brand name. In one of the most successful such joint-ventures, Renault's Dacia Logan was presented to Indian customers as Mahindra Logan and, later, as Mahindra Verito. Such joint-ventures expanded the range of components available for bricolage, thus allowing the company to make significant savings. Corroborating information from multiple respondents, we identified five main enablers of component bricolage (see Table 3 below): (i) flexible design; (ii) knowledge of existing components, which could serve envisioned purposes; (iii) the ability to adjust or "tweak" the identified components if they did not match the required performance specifications; (iv) the ability to incorporate components of various origins into a consistent and attractive design, thereby minimizing the risk of unacceptably imperfect outcomes; and (v) the modularity of the electric architecture which allowed the use of original components in multiple projects.

The notion of modular systems (i.e. independently designed sub-systems which successfully function as a whole), popular in the computer industry [32] inspired our informants. 
"We view making cars the same way as making computers, picking the desired hard drive and matching it with the required software. Nobody had viewed the cars that way and the fact that we had actually never made cars before helped us in being more innovative and flexible." (Founder and former CEO) Broadly, the electric architecture of Mahindra Reva's EVs comprises of: (i) the 'software' or the core of the company's Intelligent Energy Management System (IEMS) and (ii) the 'hardware' components such as the battery pack, the motor, the controller and the charger. The 'hardware' is produced exclusively by independent suppliers. The IEMS 'software', however, is one of the company's core capabilities and is designed to fit multiple 'hardware' combinations. The development of IEMS has given the company over 40 patents in areas such as wireless battery management, efficient braking systems, remote diagnostics and remote activation of energy.

"The IEMS works with different types of batteries [e.g. lead-acid or Li-ion]. It requires minor code changes, but it is structured to accommodate numerous variations. This is very important for us because our models use different batteries, different voltages, different numbers of cells, plus the chemistries are constantly changing. We need to be able to adapt to anything. This is the philosophy of our design." (Senior manager - New Technologies and IP)

Table 3. Component bricolage

\begin{tabular}{|l|l|l|}
\hline $\begin{array}{c}\text { Component } \\
\text { bricolage }\end{array}$ & \multicolumn{1}{|c|}{ Enabler } & \multicolumn{1}{c|}{ Illustrative quotes } \\
\hline $\begin{array}{l}\text { Combining } \\
\text { off-the-shelf } \\
\text { components }\end{array}$ & Flexible design & $\begin{array}{l}\text { "I go and look at design elements such as air vents, buttons and } \\
\text { controls which are available on our existing models cars or even } \\
\text { on IC cars and try to use some of the existing shapes and } \\
\text { characteristics. Having in mind parts that can be carried forward } \\
\text { from existing models can help us a lot in reducing costs later on. } \\
\text { Of course this can impact the uniqueness and originality of the } \\
\text { interior, but I try to push the styling with the general volumes and } \\
\text { to keep these elements quite simple I use elements which are at } \\
\text { least inspired from existing ones to make sure that suppliers } \\
\text { would be able to provide something without increasing tooling } \\
\text { costs." (Front-line employee - Styling) }\end{array}$ \\
\cline { 2 - 4 } & $\begin{array}{l}\text { Knowledge of } \\
\text { existing } \\
\text { components } \\
\text { which could } \\
\text { serve the }\end{array}$ & $\begin{array}{l}\text { a new part although something similar was already available. Here, } \\
\text { I have to be extra careful and make an effort to check if a certain } \\
\text { part is available somewhere and try to use it in a smart way." } \\
\text { (Middle Manager - R\&D Mechanical) }\end{array}$ \\
\hline
\end{tabular}




\begin{tabular}{|c|c|c|}
\hline $\begin{array}{l}\text { Component } \\
\text { bricolage }\end{array}$ & Enabler & Illustrative quotes \\
\hline \multicolumn{3}{|l|}{ bricolage } \\
\hline & $\begin{array}{l}\text { Component } \\
\text { modification } \\
\text { capabilities }\end{array}$ & $\begin{array}{l}\text { "We always try to find an off-the-shelf part which can be tweaked } \\
\text { as per our requirements. Developing original parts can take } \\
\text { months and cost lakhs of rupees. There is no point in doing that } \\
\text { if we can make a slight modification to a part which is already } \\
\text { available and can be used without incurring any development and } \\
\text { tooling costs. However, we cannot compromise on aesthetics } \\
\text { because that might affect our brand image." (Senior Manager - } \\
\text { R\&D) }\end{array}$ \\
\hline & $\begin{array}{l}\text { Design } \\
\text { alignment } \\
\text { capabilities }\end{array}$ & $\begin{array}{l}\text { "The challenge is to keep the design attractive after all this mix- } \\
\text { and match. We made the concept first and then started adapting } \\
\text { it. This way we managed to retain the intended styling. For } \\
\text { example, the control module is now a three-piece module. } \\
\text { Initially, we wanted to use a backlit button panel which was } \\
\text { glowing really nice. But that would have been really expensive. So } \\
\text { we had to adapt the design to what was available on the market." } \\
\text { (Senior Manager - Styling) }\end{array}$ \\
\hline $\begin{array}{l}\text { Using } \\
\text { components in } \\
\text { multiple } \\
\text { projects }\end{array}$ & Modular design & $\begin{array}{l}\text { "Our electric architecture is quite flexible and modular. The 40- } \\
\text { volt e2o was designed specifically for India. The } 72 \text {-volt variant is } \\
\text { for export. The electric architectures are different but it is very } \\
\text { easy for us to adapt the old one to meet the new requirements. } \\
\text { Similarly, most parts we are using now will go into the electric } \\
\text { Logan/Verito. Of course, the location and layouts will be } \\
\text { different but most of the parts are similar and easily upgradable } \\
\text { from one platform to another. This helps us to reduce costs and } \\
\text { design time." (Middle Manager-R\&D Electrical) }\end{array}$ \\
\hline
\end{tabular}

\section{Collaborative bricolage}

Innovation is often a collective process, which mobilizes the efforts and inputs of multiple actors [I8].

Mahindra Reva developed a network of partner organizations which pooled in resources. The company's strong suit was its proprietary knowledge and R\&D capability, but it lacked the resources to make significant investments in production equipment. Therefore, senior managers made the strategic decision to outsource the manufacturing of all car components to suppliers. Unlike typical outsourcing arrangements where only non-core activities are outsourced to specialized suppliers, this was an attempt to create core value in collaboration with non-specialized suppliers. In the late I990s, only a few developed-country car-makers were experimenting with EV technology and suppliers had limited or no prior experience producing components for EVs. The company collaborated with suppliers of IC vehicle components as well as with companies in seemingly tangential industries such as electronics, 
aerospace and defence. Generally, Mahindra Reva provided expertise and knowledge in EV technologies while the suppliers contributed with their knowledge and production capabilities (see Table 4 below). In this sense, the company developed common or shared "repertoires" of resources with each of its partners (see [24]). Drawing on such shared repertoires, they carried out extensive collaborative experimentation to develop components for their EVs.

Senior managers envisioned the company as a technology and knowledge hub guiding the collaborative component development. The company retained only the assembly line and relied on external vendors for the production of all car components. Although this strategic choice helped Mahindra Reva reduce investment and development costs, implementation was challenging. Mahindra Reva was a small company with limited sales volumes, which reduced its bargaining power with suppliers catering to the company's atypical requirements. Although the corporate parent - Mahindra \& Mahindra - allowed Mahindra Reva to tap into its extensive supplier base, the low volumes required by the company remained a significant problem in the relationship with suppliers. Senior managers explained that they chose Indian suppliers wherever possible as costs of established international suppliers could have significantly increased the overall cost of the car. Being dependent largely on the domestic supplier base, they patiently nurtured their suppliers' knowledge base and capabilities.

"We generally do not drop suppliers, even if at some point they do not perform up to the standard. EVs are completely new to the Indian automotive industry and we are aware that suppliers are not always knowledgeable in EV technology. We go along with them and try to educate them. [...] When we started testing the first parts our suppliers delivered, they invariably failed within the first two days of testing. We had to have a hands-on approach and help our suppliers improve their products by transferring some of the knowledge we have accumulated in the last 15 years. Otherwise, we would not have our EV." (Senior manager - Testing)

Table 4. Collaborative bricolage 


\begin{tabular}{|c|c|c|c|}
\hline $\begin{array}{l}\text { Collabora- } \\
\text { tions related } \\
\text { to }\end{array}$ & $\begin{array}{l}\text { Partner's } \\
\text { contribu- } \\
\text { tion }\end{array}$ & $\begin{array}{l}\text { Mahindra } \\
\text { Reva's } \\
\text { contribution }\end{array}$ & Illustrative quotes \\
\hline EV charger & $\begin{array}{l}\text { Knowledge } \\
\text { and } \\
\text { expertise } \\
\text { with } \\
\text { electrics and } \\
\text { electronics } \\
\text { for } \\
\text { aerospace } \\
\text { and defence } \\
\text { industries }\end{array}$ & $\begin{array}{l}\text { Automotive } \\
\text { and EV } \\
\text { expertise }\end{array}$ & $\begin{array}{l}\text { "We worked with a US-based aerospace company and } \\
\text { created a technology tie-up which helped us reduce } \\
\text { development costs of the charger by } 50 \% \text {. They were } \\
\text { interested in entering the automotive industry but had } \\
\text { no expertise in this sector. We had automotive } \\
\text { expertise, while they were very experienced with } \\
\text { electrics and electronics, so it was a mutually beneficial } \\
\text { relationship." (CEO) }\end{array}$ \\
\hline $\begin{array}{l}\text { Tubular } \\
\text { space frames }\end{array}$ & $\begin{array}{l}\text { Knowledge } \\
\text { of steel } \\
\text { welding and } \\
\text { production } \\
\text { capabilities }\end{array}$ & $\begin{array}{l}\text { EV } \\
\text { requirements } \\
\text { (stress levels, } \\
\text { vibrations, } \\
\text { crash } \\
\text { resistance) }\end{array}$ & $\begin{array}{l}\text { "We are the only company in the world using space } \\
\text { frame structure for our cars. [...] Our supplier knew } \\
\text { steel and welding and had production capabilities. We } \\
\text { understood the levels of stress and mechanical } \\
\text { vibrations the space frame will be subjected to, the } \\
\text { required reliability in case of crash, and the complexity } \\
\text { of the vehicle context. We transferred all our } \\
\text { knowledge by deputing our experts to their lines when } \\
\text { we were building the first prototypes. There was an } \\
\text { interaction and co-learning process in order to ensure } \\
\text { the frames have the required reliability in case of crash } \\
\text { and last for I5-20 years." (Senior Manager - } \\
\text { Production) }\end{array}$ \\
\hline Motor & $\begin{array}{l}\text { Production } \\
\text { capabilities }\end{array}$ & $\begin{array}{l}\text { EV-specific } \\
\text { knowledge and } \\
\text { testing } \\
\text { equipment }\end{array}$ & $\begin{array}{l}\text { "Although our supplier was very good at } \\
\text { manufacturing standard motors, they did not have the } \\
\text { capability to deliver according to our requirements. } \\
\text { We had to work together to develop all the } \\
\text { components. Today, the supplier uses the } \\
\text { dynamometer testing equipment developed by us. In } \\
\text { time we transferred the responsibility for all } \\
\text { components to them, and they now deliver according } \\
\text { to our standards. We held the supplier's hand and } \\
\text { helped with knowledge, design and equipment. } \\
\text { However, the suppliers did have the core production } \\
\text { capability which we did not have."(CEO) }\end{array}$ \\
\hline $\begin{array}{l}\text { Lead-acid } \\
\text { batteries }\end{array}$ & $\begin{array}{l}\text { Production } \\
\text { capabilities }\end{array}$ & $\begin{array}{l}\text { EV-specific } \\
\text { knowledge and } \\
\text { testing } \\
\text { equipment }\end{array}$ & $\begin{array}{l}\text { "The battery supplier for our first cars was a UK } \\
\text { company. When we brought the batteries to India we } \\
\text { found that their testing procedures were not adequate. } \\
\text { We had to work with them to find the right structure } \\
\text { and composition for the Indian conditions. We } \\
\text { developed a lot of automated testing equipment in } \\
\text { India. Once we found this equipment working so well, } \\
\text { we actually sold it to our supplier. In a way we actually } \\
\text { managed the supplier's quality by providing them } \\
\text { testing equipment customized for EVs." (CEO) }\end{array}$ \\
\hline EV gearbox & $\begin{array}{l}\text { Production } \\
\text { capabilities }\end{array}$ & $\begin{array}{l}\text { Knowledge on } \\
\text { how to design }\end{array}$ & $\begin{array}{l}\text { "Our supplier had their own aluminium processing } \\
\text { capabilities. Initially, we used to buy the castings, get }\end{array}$ \\
\hline
\end{tabular}




\begin{tabular}{|c|c|c|c|}
\hline $\begin{array}{l}\text { Collabora- } \\
\text { tions related } \\
\text { to }\end{array}$ & $\begin{array}{l}\text { Partner's } \\
\text { contribu- } \\
\text { tion }\end{array}$ & $\begin{array}{l}\text { Mahindra } \\
\text { Reva's } \\
\text { contribution }\end{array}$ & Illustrative quotes \\
\hline & & $\begin{array}{l}\text { and build EV } \\
\text { gearboxes }\end{array}$ & $\begin{array}{l}\text { our staff with the casting to the supplier's plant, and } \\
\text { get the castings processed using their equipment. Then } \\
\text { we would get the castings back and do the assembling } \\
\text { ourselves. In time, we transferred the know-how to the } \\
\text { supplier and now they take care of everything and } \\
\text { supply the complete gearbox." (Senior Manager - } \\
\text { Prototypes) }\end{array}$ \\
\hline
\end{tabular}

Some suppliers (e.g., the manufacturer of exterior body panels) derived significant benefits from the knowledge developed in collaboration with Mahindra Reva. Our informants observed that this supplier grew at a faster rate than Mahindra Reva itself. Initially, the company had been the supplier's first and only client. Over time, however, the co-developed technology allowed the supplier to find other clients and significantly increase sales. At the time of the study, Mahindra Reva accounted for less than $30 \%$ of the production of this supplier. Thus, collaborative bricolage can be viewed as an intensely cooperative form of collective bricolage (see [I8], [24]) wherein each bricoleur firm disclose and share resources with their partner(s) and actively contribute to the emergence of a desired outcome. In this sense, collaborative bricolage at Mahindra Reva involved several bi-directional and multidirectional knowledge sharing processes.

"In the design phase of the e2o model there was a process of continuous improvement. Some of the improvements were dependent on the parts provided by our suppliers. This involved a co-learning process, correlating our knowledge base with that of the suppliers." (Senior manager - Sourcing and Supply Chain)

"We tend to stick with the suppliers with whom we have a good collaboration because we are very familiar with their capabilities and we understand how they could support us either in the design process or by sharing some of the initial investment." (Middle Manager - New Product Development)

Garud and Karnoe [18] argued that geographical proximity plays a critical role in collective bricolage ventures as actors with vested interests can contribute with inputs and share resources more easily in a closely-knit network. In a similar vein, our informants described successful collaborations 
with Bangalore-based suppliers in which close interactions played a central role. Many informants used phrases such as "we worked closely together" or "they sat down with us" to describe the interactions with collaborating organizations. In other words, tacit knowledge sharing was an important component of Mahindra Reva’s collaborative bricolage activities.

"The charger is supplied by an Indian partner. They make this charger only for us. Initially, we tried to work with well-established foreign companies. The tooling costs were a lot higher and there were problems with logistics and delivery times. They were also asking for a 10,000-unit volume commitment. Our current supplier is located near-by and we have had a long term relationship with them, they sat down with us and adjusted their product according to our needs and we did not incur large tooling costs." (Senior manager - Sourcing and Supply Chain)

Engineering the bricolage

Departing from Levi-Strauss' [I4] perspective which viewed the bricoleur and the engineer as opposite figures, our findings indicate that for Mahindra Reva the bricolage and engineering approaches to technology development are more complementary than contradictory.

"What we do today is a mix of the two approaches. When we do a prototype we quickly produce a solution to prove that the concept works. This approach is all about having a practical orientation rather than a very structured, process-oriented approach to problem solving. But later, our R\&D department takes the knowledge about how the concept works provided by the prototypical illustration and creates a very structured process to create a mass-manufacturable product. That requires all the engineering capabilities that we can muster." (Senior manager - Mobility Solutions)

In order to manage with the limited resources and to meet the challenge of keeping the cars' selling price low, the company departed from conventional practices in the automotive sector and used bricolage processes to develop components. Such components needed adaptations, improvements, and tests to be turned into products that could successfully address the needs of a multitude of users/consumers. Thus, our informants explained that the process of legitimizing bricolage in the eyes of customers and competitors required the rigour of engineering methodologies well-established in the 
automotive industry. For instance, in order to ensure consistency and formalize the collaborative bricolage activities with their suppliers, the company adopted conventional practices popularized by Japanese automakers in the 1980s. These included: (a) involving suppliers in the early stages of designing new products (see [7], [33]) to reduce costs and design times, and (b) providing only the envisioned functionality of the components rather than specifying their design, and transferring the responsibility of the entire design to suppliers [7], [33].

"We refer to the involvement of suppliers in the new product development as 'vendor on board". The earlier we take the vendor on board, the better it is for the project. Ideally, we should get the vendor on board at the time of concept designing. We shortlist a few suppliers with whom we are currently working or have collaborated in past and we invite them over. Then they provide input based on their experience and production capabilities. Because we usually already have a working relationship with these suppliers for other projects or parts, they are happy to contribute with their input although at this point there is no written agreement." (Senior manager - R\&D)

Similar to Japanese companies, which also relied on suppliers located in their vicinity [7], our informants explained that geography is central to their supplier selection strategy.

"We are located in Bangalore. Say there is a supplier in Bangalore and a Mahindra \& Mahindra supplier in Mumbai. We'd rather go with the Bangalore supplier... geographical proximity can trump the affiliation with Mahindra \& Mahindra. Geographical proximity is very important not only for reduced transportation and handling costs, but also for our interaction with the suppliers. If a problem arises we make a phone call and they can come down within an hour." (Senior manager - Sourcing and Supply Chain)

Cost engineering is another example of established practice implemented by the company. Cost engineering refers to a systematic approach aiming to efficiently balance costs, quality and time requirements [34]. According to our informants, cost engineering is a practice religiously followed at Mahindra Reva as the company's goal is to develop EVs, which would compete, price-wise, with conventional cars. 
"We design-to-cost. The cost is driving our designs. We cannot design a part and only later on worry about the costs. We would end-up investing lots of money and the car would end-up costing as much as the EVs our competitors are offering. Our EV has to be the most affordable in the world. We think of the cost implications of every line we draw in the design of a component. [...] We always think of ways and means to develop a product with minimum investment, time and part costs. This is the basis of design at Mahindra Reva." (Senior manager - R\&D)

\section{Discussion}

The analysis above highlighted three crucial types of bricolage activities (the recombination of resources for new purposes, component bricolage and collaborative bricolage). According to our informants' estimates, Mahindra Reva has spent only about I\% of the amount invested by competing carmakers such as GM and BMW for the development of their EV models. The company's bricolagebased strategy delivered outcomes at two distinct levels, which we have termed as operational and strategic (see Figure I below). The creative recombination of resources allowed the company to significantly reduce the costs involved in the testing and production processes. For instance, by developing testing equipment in-house from basic EV components such as motors and chargers, the fixed costs (e.g., for testing rigs) incurred by most other companies in the automotive sector were avoided. Through component bricolage (i.e., by using off-the-shelf components and parts, which suppliers could produce using equipment and tools already in place), the company saved on initial tooling costs and at the same time ensured that they did not have to deal with suppliers' demands for big volume commitments. The outsourcing partnerships-led collaborative bricolage helped the company conduct its product development without any capital investments in production equipment.

The bricolage approach also helped the company achieve what could be termed as important strategic outcomes (see Figure I below). The reduced costs achieved through creative use of resources and the small tooling investments resulting from component bricolage drove down the selling price of the company's EVs. Similarly, with collaborative bricolage approaches the company's fixed costs (e.g., R\&D facilities and assembly plant) not only became very small relative to industry standards but were 
also amenable to amortization over multiple projects. Thus, with fewer and smaller capital investments the company was also able to achieve low break-even points. Overall, these outcomes suggest that bricolage was a deliberately orchestrated strategy, which helped the company mitigate the risks of developing new technologies in an emerging market setting.

Figure I. Operational and strategic outcomes of bricolage

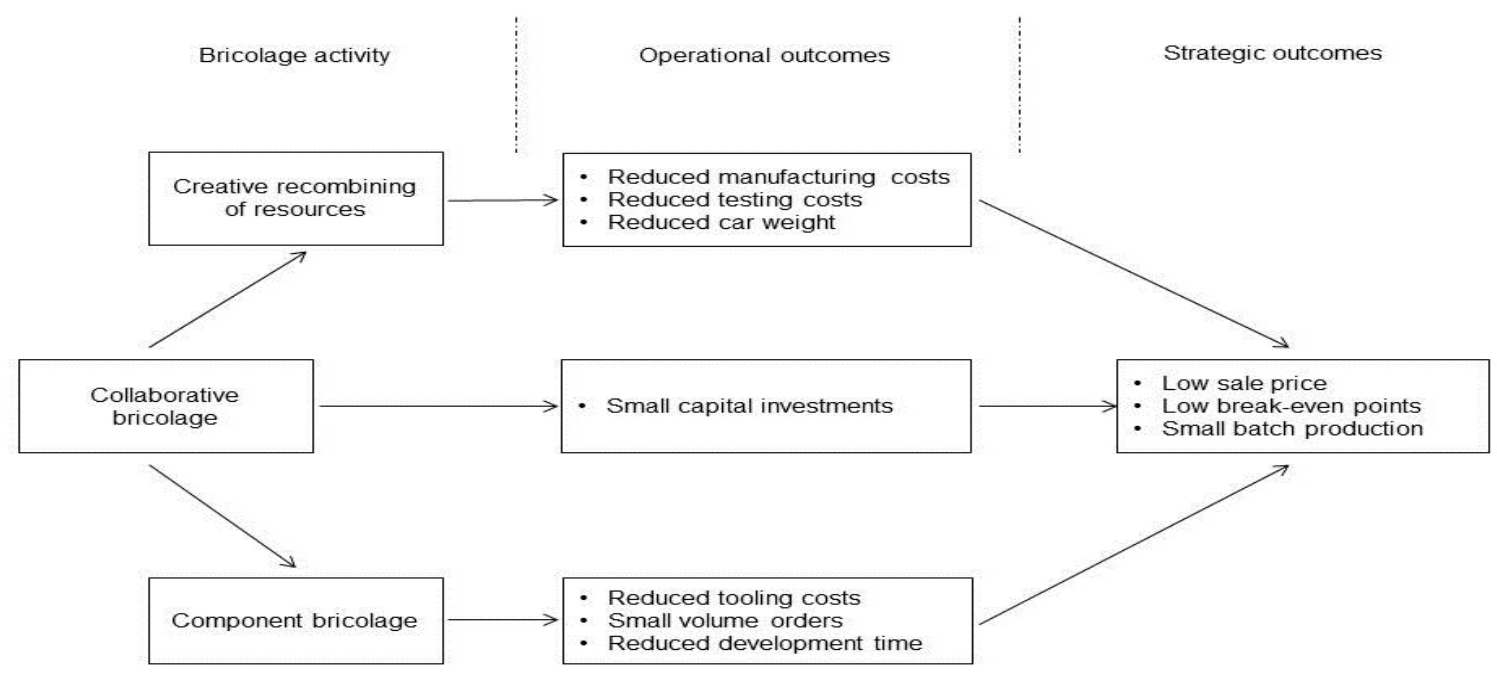

\section{Contributions to innovation research}

This paper suggests that the notion of bricolage offers a structured and deeper explanation of how resource-constrained and frugal emerging market innovations come about. The complex contexts within which technological innovations in emerging markets take place demand nuanced theorizing, which can account for both endogenous and exogenous categories of challenges. The multi-layer bricolage framework presented here is one such theorizing attempt. The bricolage strategy employed helped Mahindra Reva overcome endogenous constraints (e.g., lack of resources) as well as addressed some key exogenous challenges (e.g., customers' price expectations). In this sense, frugal innovations can be viewed as an outcome of carefully designed and orchestrated bricolage strategies.

The findings from the case also show how a bricolage strategy can be central to the development of a discontinuous innovation. EVs are currently causing technological discontinuities as the technology is relatively new for customers, firms, and indeed for the entire automobile industry. The extant capabilities of established automotive companies may not be enough to develop EVs. New 
knowledge bases need to be developed, numerous technical solutions need to be scoured, tested and improved, new production lines and infrastructures (e.g. charging facilities) must be set in place for EVs to become commercially viable products. Many EV makers have difficulties identifying appropriate market segments for their products. IC vehicles are a ubiquitously accepted technology and it is very difficult for EV producers to identify 'target markets'. At the same time, in order to take full advantage of the benefits offered by EV technology users of conventional automobiles will have to change their behaviours and commuting habits. Bringing to market discontinuous innovations such as an EV could take a long time and can be a highly expensive and risky process [35]. This paper shows how in such scenarios, a bricolage strategy featuring practices significantly different from those used for continuous or incremental innovations (see [35]) can underpin the development of products which have the potential of generating technological discontinuities and market disruptions.

Drawing on multiple case studies, Lynn et al. [35] documented an investment-intensive, iterative 'probing and learning' as a strategy conducive to the successful commercialization of discontinuous innovations. In Mahindra Reva's case, probing and learning helped the company transition from the first Reva EVs which were very small (the rear seats allowed sufficient space only for one or two small children) to develop the recent e2o model which is significantly more spacious and powerful than the Reva. The company learnt from selling the earlier Reva model that many Indian consumers regarded cars as symbols of social status and, therefore considered diminutive and underpowered models such as Reva to be unappealing. This knowledge helped the company develop the e2o model. Interestingly, our informants observed that they conducted their probing and learning using only a very small fraction of the resources invested in similar projects by competitors such as GM, Tesla and BMW. This would suggest that a bricolage strategy can make the process of developing discontinuous innovations significantly less costly, thus reducing the risks associated with developing products for which a clear market has not yet been identified as well as allowing for an increased number of probing-and-learning iterations. Such iterations can turn out to be crucial for the successful commercialization of discontinuous innovations not only because they help companies improve their 
product, but also because each step helps potential customers become familiar with technologies, which they might otherwise greet with scepticism.

This paper also shows how bricolage strategies may address (at least to some extent) the "sales" challenge posed by disruptive technologies [30]. "EVs have the smell of a disruptive technology" [30, p. I89] in addition to being a discontinuous innovation. While IC cars are far superior to EVs in terms of performance along mainstream attributes such as top speed and driving range with one charge, it is becoming increasingly evident that current performance levels of IC cars far exceed their practical applicability (see [36], [37]). Their advertised top-speeds far exceed the permissible legal speed-limits in most countries [37]. Moreover, studies have also shown that on average, two-leg car journeys taken for many private or business activities do not exceed 50 miles [36], thereby making 300-mile driving ranges on a single fuelling irrelevant for a significant number of practical commuting patterns. Such performance "overshooting" or "oversupply" [30] suggests that the global automobile market may be ripe for disruption by innovative technologies [30], [37]. Yet, the adoption rate of EV technology is still not very high. The reticence of mainstream users regarding EVs is most likely caused by the price of EVs which significantly exceeds that of similarly sized IC cars. EV-related market research indicated that less than $5 \%$ of customers are willing to pay the price premium currently demanded by EVs relative to conventional cars [36]. As Adner [38] suggests, "while disruption is enabled by sufficient performance, it is enacted by price" (p. 686). As our analysis shows, by keeping product development costs low, bricolage strategies can help companies significantly reduce selling prices and improve sales.

In addition, the findings from our case reinforces and adds to prior research (e.g., [39], [40]), which has suggested that emerging markets are an apt setting for the introduction of disruptive innovations. BOP (base-of-the-pyramid) and MOP (middle-of-the-pyramid) consumers from emerging markets may have lower performance requirements from disruptive innovations than high-income developed-country consumers. Indeed, prior studies [39], [40] have documented several such innovations developed through the paring down of mature technologies such as IC cars, microwave ovens, refrigerators and mobile telecommunication services, and aimed at BOP-MOP consumers. 
Examples of companies introducing more radical to emerging markets are, however, sparse. This case study shows how a small, resource-constrained emerging market company can develop and offer consumers a nascent and potentially disruptive technology product.

\section{Contributions to the bricolage literature}

This paper contributes to the bricolage literature in several ways. First, while prior research has described bricolage as an antecedent or skill (e.g., [I], [I2]) or entrepreneurial behaviour (e.g., [I3]), our study demonstrates how bricolage can also be a carefully planned and executed strategy, especially in contexts that require companies to improvise heavily. Through its business model, Mahindra Reva carefully planned and executed its technological innovation. Thus, while bricolage implies a preference and inclination for active problem-solving, it can also incorporate very extensive planning and strategizing.

Scholarly literature suggests that multiple organizations involved in collaborative bricolage build shared repertoires and that tacit knowledge is an important component for such communal repertoires of resources [24]. However, as far as we can tell, this body of research has illustrated collaborative bricolage mostly using secondary data (e.g., [I8]) and discussions around the development of shared repertoires has been largely theoretical (e.g., [24]). Our empirical material corroborates Duymedjian and Ruling's [24] suppositions by showing that collaborating bricoleurs need to become familiar with each other's resource repertoire to the point where the resources pooled-in by the bricoleurs become a shared repertoire. We would argue that Mahindra Reva strategized the development of the shared repertoire quite differently from the typical collaborative strategies of larger companies. While such companies encourage technology sharing in their outsourcing agreements, they tend to be very restrictive about their suppliers' engagement with other customers. By contrast, our informants reported that they did not mind suppliers servicing other companies using components codeveloped with Mahindra Reva. Senior managers took the view that suppliers would achieve economies of scale if they expanded their client portfolios and (i) they would become less rigid in their demands for bigger volume commitments; (ii) Mahindra Reva would pay lower prices for components. Our 
analysis also highlights how geographical distance between bricolage partners has a significant bearing on the development of a shared repertoire. Development of shared repertoires calls for extensive social interaction and transfer of tacit knowledge. Despite recent progresses in information and communications technologies (ICT) which have significantly reduced the cost of information exchanges and enabled virtual meetings, video conferences etc., tacit knowledge sharing generally requires a shared physical presence. Our case empirically demonstrates how the development of shared repertoires happens best in a closely-knit and co-located network of bricoleurs.

Figure 2. EV development process and interplay of bricolage activities

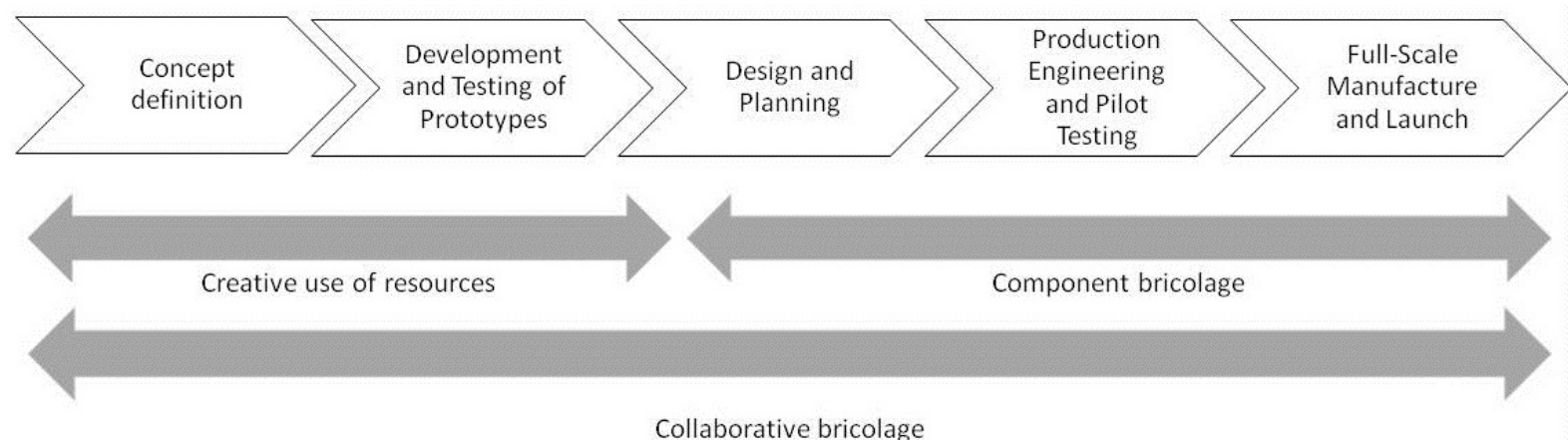

Second, the paper shows how multiple types of bricolage activities could relate to different stages of the innovation process in emerging markets (see Figure 2 above). Our findings indicate that the creative use of resources was predominant in the concept definition, prototype development and testing stages, while component bricolage was prevalent in later stages such as design, production engineering, and full-scale manufacture. This strategy is probably explained by the fact that when Mahindra Reva started its work on EVs in the mid I990's, there were very few suppliers of EV-specific components in the world. In India no company had any experience with EV technology development. Thus, the concept definition and prototype development at Mahindra Reva involved a wide-ranging search for resources and extensive experimentation. On the other hand, design, production engineering and full-scale manufacturing stages involved working mainly with common mechanical parts and design components. For these latter stages numerous automotive suppliers were locally available and, thus, the company relied on off-the-shelf components developed originally for other vehicles. Collaborative bricolage played a significant role throughout in that strong relationships and collaborations with suppliers 
underpinned the entire product development process. For example, the adjustment and tweaking of offthe-shelf parts (i.e. component bricolage activities) required the support and production capabilities of suppliers.

Third, contrary to prior research which described the bricoleur and the engineer as opposing figures [I4], [24], Mahindra Reva's experience indicate that bricolage and engineering can be complementary, rather than mutually exclusive activities (see Figure 3 below). On the one hand, bricolage allows the creative use of resources, thereby enabling resource-constrained innovation. On the other hand, engineering processes consolidate the legitimacy of the innovator (see [24]) by preventing and correcting the imperfections of bricolage outcomes. At Mahindra Reva, bricolage was predominant in the concept definition, prototype development, and (in part) design stages. In these stages, the company sought workable alternatives and experimented extensively by mixing-and-matching components.

Figure 3. EV development process and interplay of bricolage and engineering

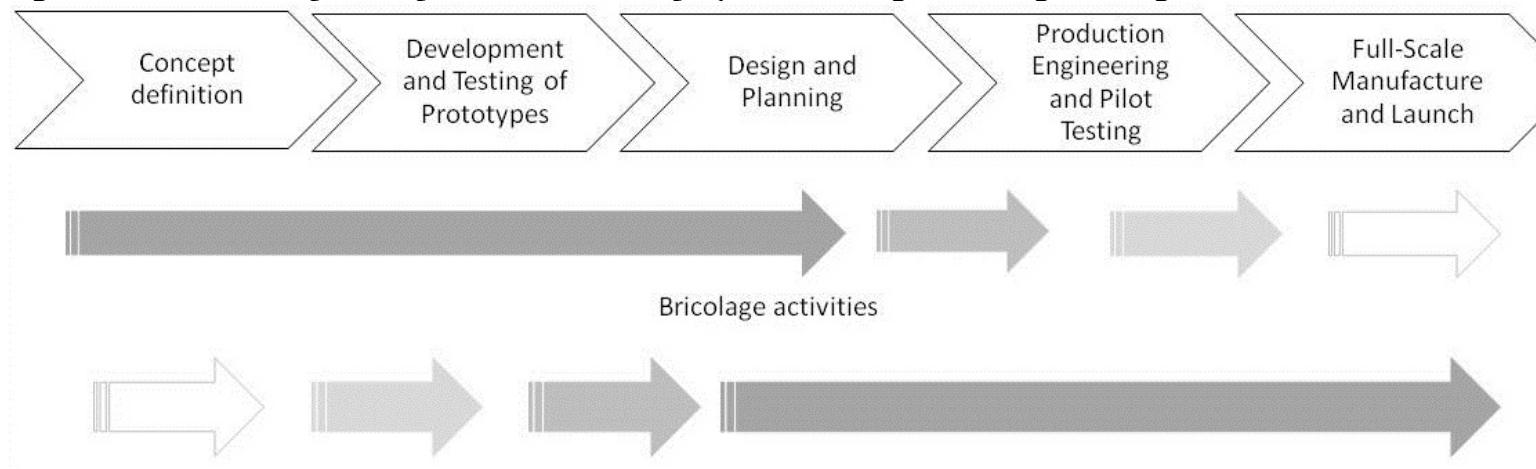

Engineering

However, during production engineering and full-scale manufacture there was little room for imperfections. Thus, in these stages engineering methodologies were predominant. We would also argue that in some respects bricolage and engineering complement each other throughout the product development process. For example, while the development of battery packs for EVs could be an instance of bricolage, it also involves extensive chemical engineering and simulation efforts. Similarly, production engineering could rigorously follow well-established engineering practices while relying on off-the-shelf components and extensive collaborative bricolage. 


\section{Managerial implications}

This paper complements prior research which has suggested that a good way for emerging market firms to catch up with their developed-country competitors in terms of their technological capabilities is to enter early into new technological systems (e.g., [27]). The experience of Mahindra Reva shows that such ambitions are not outside the reach of emerging market firms despite the resource constraints and institutional voids they face. With creative resource recombinations and innovative collaborations emerging market managers can turn their firms' resource limitations into significant cost advantages at a global level. Strategies and business models "that are forged in low-income markets travel well" [39, p. 52]; that is, they can be successfully redeployed in high(er)-income markets. Managers in emerging market companies may find some of the practices discussed in the paper useful and relevant to their plans of disrupting the global market with high-tech discontinuous innovations. The findings further suggest that nurturing a pragmatic mind set amongst the workforce, embracing flexibility in organizational design and dismantling rigid organizational structures will increase enactments of competitive bricolage-led strategies.

Developed country multinational enterprises (DMNEs), which consider entering emerging markets can benefit from exploring and understanding the strategies of local competitors. Strategies and business models from the developed world may not always find success in emerging markets. The arguments of our paper can help DMNE managers derive "contextual intelligence" [4I] which is often crucial for the development and deployment of successful business models in emerging markets. Given the global economic downturn, companies all over the world are experiencing in one form or another many of the challenges faced by companies in emerging markets. In this sense, only a few DMNEs may be able to afford very expensive $R \& D$ endeavours or find it is reasonable to do so. Breakthroughseeking innovation strategies usually imply high prices for the resulting products, while many consumers are cutting-back on their expenditures and favouring low-priced items (e.g., [I], [40]). Our case study provides some insights into how managers might employ bricolage as a cost and risk reducing strategy for innovation and new product development, particularly when working with 
discontinuous and disruptive technologies. Many DMNEs may be reluctant to accept bricolage-led approaches as a legitimate innovation strategy in its own right, especially if they have been successful innovators in the past. However, we would argue that unless they adjust and adapt their mental models to new contexts, they may find themselves facing stern competition from emerging market challengers, who are poised to develop high-tech, but affordable innovations for BOP-MOP consumers.

\section{Limitations and future research}

Our findings are based on a single case study. Obviously, there will be variations in the extent to which our findings are transferable to other contexts or industries, be it in emerging markets or developed countries. Some caution must be exercised in generalizing these findings, although we would suggest that bricolage strategies like the one presented here may work well for new, small companies in a range of nascent industries.

Glorifying bricolage was not the aim of this paper. It is worth noting that bricolage is not a bullet-proof strategy for sustainable competitive advantage. Rather it should only be viewed as a costeffective strategy for developing discontinuous and disruptive technologies. It may not necessarily guarantee better sales and profits. In fact, despite developing perhaps the most affordable EVs in the world, it is worth noting that Mahindra Reva has not yet been very successful in penetrating the Indian automobile market. Competition from manufacturers of low-cost conventional cars in the Indian market (e.g., Tata, Maruti Suzuki, Hyundai etc.), the absence of governmental subsidies for $\mathrm{EVs}^{3}$ and the underdeveloped EV-specific infrastructure have meant that the achievements of the company's bricolage strategy in pure financial terms have been rather modest. We are therefore not in a position to claim that these EVs have received a rousing reception in the market. However, this does not take away from the main argument of the paper: a carefully planned and implemented bricolage strategy helped the company produce a technologically sophisticated and innovative product. Recent reports in the

\footnotetext{
${ }^{3}$ It appears that the Indian government is all set to offer financial incentives to EV producers in the near future. (http://indianexpress.com/article/business/business-others/with-budget-boost-electriccars-may-become-cheaper/)
} 


\section{A bricolage perspective on technological innovation in emerging markets}

business press suggest that the company is considering an elaborate internationalization strategy. It remains to be seen how well Mahindra Reva's EVs will perform in developed markets which arguably have more favourable conditions (for instance, availability of state subsidies for EVs).

It would be interesting to explore using larger data sets the contextual elements which support and hinder bricolage-led strategies for technology innovation. More empirical work is needed to examine how factors such as the characteristics of the innovating company (e.g. size, age, origin, etc.), the targeted market (e.g. low-income vs. middle-income and high-income), the nature of the innovation (e.g. discontinuous and disruptive vs. sustaining and incremental) and the stage in the technology lifecycle impact a company's bricolage strategies. Another fruitful line of research is the impact of organizational and national cultures on a company's propensity to engage in bricolage.

\section{Concluding Remarks}

This paper adds to the small, but growing body of scholarly literature, which has examined strategies employed by emerging market companies in their technological innovation efforts. We drew on the notion of bricolage to capture and explain the technology and new product development approach at Mahindra Reva, the only EV producer in India. We demonstrated how a multi-level bricolage strategy helped the company overcome resource-constraints and develop affordable EVs using minimal investments relative to developed-country competitors. We have shown how bricolage strategies could be particularly relevant in the case of discontinuous and disruptive innovations where the technology is in its infancy and the market is ill-defined, leading companies to embark on an iterative market testing process involving the launch of various versions of the product. In this sense, the analytical scope of the notion of bricolage extends beyond resource-constrained emerging market companies and could help explain the delivery of affordable and innovative products more generally.

\section{References}

[I] H. Ernst, H.N. Kahle, A. Dubiel, J. Prabhu, and M. Subramaniam, "The antecedents and consequences of affordable value innovations for emerging markets," J. Prod. Innov. Manage, in press, 20I4. DOI: I0.IIII/jpim.I2I7I. 
[2] V. Govindarajan and R. Ramamurti, "Reverse innovation, emerging markets, and global strategy," Global Strategy J., vol.I, pp. I9I-205, 20 II.

[3] C.K. Prahalad and R.A. Mashelkar, "Innovation's Holy Grail," Harvard Bus. Rev., vol. 88, no. 7/8, pp. I32-I4I, 2010.

[4] A. Sharma and G.R. Iyer, "Resource-constrained product development: implications for green marketing and green supply chains,” Ind. Marketing Manage., vol. 4I, pp. 599-608, 2012.

[5] C. Dhanaraj and T. Khanna, "Transforming mental models on emerging markets," Acad. Manage. Learning \& Educ., vol. I0, no. 4, pp. 684-70I, $201 \mathrm{I}$.

[6] T. Khanna and K. Palepu, Winning in emerging markets: A road map for strategy and execution. Boston, MA, USA: Harvard Business Press, 2010.

[7] S. Ray and PK. Ray, "Product innovation for the people's car in an emerging market," Technovation vol. 3I, pp. 2I6-227, 201 I.

[8] M.J. Eyring, M.W. Johnson, and H. Nair, "New business models in emerging markets," Harvard Bus. Rev., vol. 89, no. I/2, pp. 89-95, $201 \mathrm{I}$.

[9] P. Williamson and M. Zeng, "How to meet China's cost innovation challenge," Ivey Bus. J. vol. 72, no. 3, pp. I-7, 2008

[IO] F. Wan, P. Williamson, and E. Yin, "Antecedents and implications of disruptive innovation: Evidence from China," Technovation, in press, 2014, http://dx.doi.org/I0.I0I6/j.technovation.2014.05.0I2i

[I I ] Y. Atsmon, P. Child, R. Dobbs, and L. Narasimhan, "Winning the $\$ 30$ trillion decathlon: Going for gold in emerging markets," McKinsey Quart., 2012, no. 4, pp. 20-35, 2012.

[12] M.P. Cunha, A. Rego, P. Oliveira, P. Rosado, and N. Habib, "Product Innovation in ResourePoor Environments: Three research streams," J. Prod. Innov. Manage., vol. 3I, no. 2, pp. 2022I0, 2014.

[I3] T. Baker and R.E. Nelson, "Creating something from nothing: Resource construction through entrepreneurial bricolage," Admin. Sci.Quart., vol. 50, pp. 329-366, 2005.

[I4] C. Levi-Strauss, The savage mind. Chicago, IL, USA: University of Chicago Press, I966. 
[I5] N. Radjou, J. Prabhu, and S. Ahuja, Jugaad innovation: Think frugal, be flexible, generate breakthrough growth. San Francisco, CA: Jossey-Bass, 2012.

[I6] N. Kumar and P. Puranam, "Frugal engineering: An emerging innovation paradigm," Ivey Bus. J. vol. 76, pp. I4-I6, 2012.

[I7] M. Di Domenico, H. Haugh, and P. Tracey, "Social bricolage: Theorizing social value creation in social enterprises," Entrep. T. \& P., vol. 34, no. 4, pp. 68I-703, 2010.

[I8] R. Garud and P. Karnoe, "Bricolage versus breakthrough: Distributed and embedded agency in technology entrepreneurship,” Res. Policy, vol. 32, pp. 277-300, 2003.

[19] GF. Lanzara, "Between transient constructs and persistent structures: Designing systems in action," J. Strategic Inf. Sys, vol. 8, pp. 33I-349, 1999.

[20] T. Baker, A.S. Miner, and D.T. Eesley, "Improvising firms: Bricolage, account giving, and improvisational competency in the founding process,” Res. Policy, vol. 32, pp. 255-276, 2003.

[2I] T. Baker, "Resources in play: Bricolage in the Toy Store(y)," J. of Bus. Venturing, vol. 22, pp. 694-7I I, 2007.

[22] K.E. Weick, The social psychology of organizing. Reading, MA: Addison-Wesley, I979.

[23] http://www.theguardian.com/global-development/20I4/jan/3I/tata-nano-safety-crash-testresults (accessed I3.07.2015)

[24] R. Duymedjian and C.C. Ruling, "Towards a foundation of bricolage in organization and management theory," Org. Stud., vol. 3I, no. 2, pp. I33-I5I, 2010.

[25] C.U. Ciborra, "The platform organization: Recombining strategies, structures, surprises," Org. Sci., vol. 7, pp. I03-I 18, 1996.

[26] S. Awate, M.M. Larsen, and R. Mudambi, "EMNE strategies in the wind turbine industry: Is there a trade-off between output and innovation capabilities?” Global Strategy J., vol. 2, no. 3, pp. 205-223, 2012.

[27] D. McMahon and H. Thorsteinsdottir, "Pursuing endogenous high-tech innovation in developing countries: A look at regenerative medicine innovation in Brazil, China and India," Res. Policy, vol. 43, pp. 965-974, 2013. 
[28] M.S. Sandeep and M.N. Ravishankar, "The continuity of underperforming ICT projects in the public sector", Inf. and Manage., vol. 5I, no. 6, pp.700-7II,20I4.

[29] H. Blumer, "What is wrong with social theory?" Am. Socio. Rev., vol.18, pp: 3-I0, 1954.

[30] C.M. Christensen, The innovator's dilemma: When new technologies cause great firms to fail. Boston, MA, USA: Harvard Business School Press, I997.

[3I] A. Strauss and J. Corbin, Basics of qualitative research: Techniques and procedures for developing grounded theory. Thousand Oaks, CA, USA: Sage, I998.

[32] C.Y. Baldwin and K.B. Clark, "Managing in an age of modularity," Harvard Bus. Rev. vol. 75, no. 5, pp. 84-93, 1997.

[33] K.B. Clark and T. Fujimoto, Product development performance. Boston, MA, USA: Harvard Business School Press, 199I.

[34] S. Amos, Skills and Knowledge of Cost Engineering (5 $5^{\text {th }}$ ed.). Morgantown, WV, USA: AACE International, 2004.

[35] G.S. Lynn, J.G. Morone, and A.S. Paulson, "Marketing and discontinuous innovation: The probe and learn process," Cal. Manage. Rev., vol. 38, no. 3, pp. 8-37, 1996.

[36] [British] Energy Technology Institute, Transport: An affordable transition to sustainable and secure energy for light vehicles in the UK. 20II, Available at: http://eti.co.uk/downloads/literature/ETI_Transport_Insights_Report.pdf

[37] P. Klenner, S. Husig, and M. Dowlin, "Ex-ante evaluation of disruptive susceptibility in established value networks: When are markets ready for disruptive innovations," Res. Policy, vol. 42, pp. 914-927, 2013.

[38] R. Adner, "When are technologies disruptive? A demand-based view of the emergence of competition,” Strategic Manage. J., vol. 23, pp. 667-688, 2002.

[39] S.L. Hart and C.M. Christensen, "The great leap: Driving innovation from the base of the pyramid,” MIT Sloan Manage. Rev., vol. 44, no. I, pp. 5I-56, 2002.

[40] C.C. Markides, "How disruptive will innovations from emerging markets be?" MIT Sloan Manage. Rev., vol. 54, no. I, pp. 22-25, 2012.

[4I] T. Khanna, "Contextual intelligence," Harvard Bus. Rev. vol. 92, no. 9, pp. 58-68, 2014. 